\title{
LAND TITLES - FRAUD - THE MEANING OF "FRAUD" UNDER SECTION 203 OF THE ALBERTA LAND TITLES ACT ZBRYSKI v. CITY OF CALGARY
}

The recent case of Zbryski v. City of Calgary ${ }^{1}$ decided in the Alberta Supreme Court, shows a failure on the part of the Court to give recognition and effect to section 203 of the Alberta Land Titles Act. ${ }^{2} \mathrm{Mr}$. Justice Turgeon, in Hackworth v. Baker, ${ }^{3}$ stated that the effect of the equivalent of section 203 in the Saskatchewan Land Titles Act ${ }^{4}$ is as follows:

... a person taking a transfer from the registered owner shall not, except in the case of his own fraud, be affected by any notice given him of another's equity or unregistered interest in the land; that further on this point, knowledge of such equity or unregistered interest shall not be considered a fraud; and it is expressly set out that this protection is to be given to the purchaser 'any rule of law, or equity to the contrary nothwithstanding.'s

It is important to note from the above that one ground for finding fraud at common law, that of knowledge of another's interest, is abrogated by section 203.

In the Zbryski case the plaintiff purchased for his wife land described as Lot A, Block 16 on a certain plan, believing that Lot A consisted of the whole city block. From 1927 until 1962 the plaintiff and his wife lived on Block 16 and farmed the entire Block, including Lots C and D, although Lots $C$ and $D$ were actually registered in the name of the local municipal district. In 1934 the municipal district was incorporated into a village. In 1953 the village was incorporated into a town. On January 1, 1962, the town was annexed by the City of Calgary. During this 35-year period the registered ownership of Lots $C$ and $D$ was never changed, although the plaintiff's wife was assessed taxes over the whole period and the plaintiff paid the taxes. When the City annexed the town, the latter provided the former with a list of property owned by it. Lots $C$ and $D$ did not appear on the list. The City did not learn that Lots $C$ and $D$ were registered in the name of the municipal district until November, 1962, when the plaintiff approached the City's Land Department to seek to have title to Lots C and D transferred to himself. The Land Department wrote to the plaintiff asking for a statutory declaration concerning occupation of Block 16 and informed the plaintiff that his request would be considered by the Land Committee at its November 30th meeting. (Some time prior to the November 30th meeting, and possibly as early as the plaintiff's first visit to the Land Department, the plaintiff obtained the services of a solicitor.) The plaintiff supplied the statutory declaration on November 26th. The request was not considered at the November 30th meeting and the plaintiff was informed that consideration would be given to it at the December 14th meeting, but no such meeting was held. However, the Land Department, having acquired all the facts from the town, its predecessor Municipal bodies, and the plaintiff's statutory declaration, decided that the plaintiff

1 (1965), 51 D.L.R. (2d) 54.

2 R.S.A. 1955, c. 270.

\&.S.S. 1930, c. 80 , 8. 216 (now R.S.S. 1965, c. 115 s. 237).

Ante, n. 3, at 333 . 
was not entitled to a transfer. The City then obtained registration of its title to Lots C and D in the local Land Titles Office.

At no time previous to the Land Department's decision was the plaintiff encouraged to take any steps to perfect his claim to title, nor was any representation made to him that the City would perfect his claim to title for him. The City merely deliberated on the matter until all the facts were ascertained. The plaintiff and his solicitor apparently proceeded on the assumption that the plaintiff had acquired a legal right to title by virtue of his adverse possession for the 35-year period. It appears that they expected the City to recognize this right and perfect the plaintiff's title for him while ignoring its own rights under the Land Titles Act. ${ }^{-}$The plaintiff's solicitor did not file a caveat on the certificate of title to Lots $\mathrm{C}$ and $\mathrm{D}$ until after the City obtained registration of its title to them. The plaintiff then brought action asking for the cancellation of the City's title and the issue of a new certificate of title for the property in his name. He based his claim on the fact that he had been adversely in possession of the property for 35 years and had also been assessed property taxes thereon in each of those years. The City based its case primarily upon the effect of its becoming registered owner, arguing that it is registration that gives or extinguishes title; that a registered owner has the right to give good title, and that it is a new title which starts time running when there is adverse possession.

Mr. Justice Farthing held that the plaintiff had become owner of the land by adverse possession, and that the City was estopped from denying the plaintiff's title because of its fraud. No mention of section 203, nor indeed of the Land Titles Act, appears in the judgment. He ordered that the City's title be cancelled and a new certificate of title be issued in the plaintiff's name.

Before proceeding to a discussion of fraud, it is helpful to review the statutory provisions which enable a person in adverse possession of land to become registered as owner. Zbryski's right to, and means of, obtaining a certificate of title to the land by way of adverse possession is found in sections 18 and 44 of the Limitation of Actions Act, ${ }^{7}$ and sections 73 and 74 of the Land Titles Act. Section 18 of the Limitation of Actions Act bars an action by the registered owner for the recovery of land which has been adversely possessed for more than 10 years. Section 44 of the Limitation of Actions Act states that after the expiration of this 10-year period the right and title of the registered owner of the land are extinguished. However, section 44 has been held to be inconsistent with the indefeasibility provisions of the Land Titles Act, the ruling being that the latter Act shall prevail. ${ }^{8}$ Section 73 of the Land Titles Act permits a person recovering a judgment pursuant to the Limitation of Actions Act to file a certified copy of the judgment in the Land Titles Office. If the Registrar is satisfied that no appeal is being taken from the judgment he shall cancel the existing certificate of title according to the tenor of the judgment. Section 74 of the Land Titles Act states that upon such cancellation the Registrar shall grant to the

6 Ante, n. 2.

8 Dobek v. Jennings, [1928] 1 D.L.R. 736 (Alta. C.A.), followed in Boyczuk v. Perry, [1948]

1 W.W.R. 495 . 
transferee a certificate of title. The plaintiff's counsel relied only on . the provisions of the Limitation of Actions Act and, as already mentioned, section 18 gives an adverse possessor only a bare right upon which to proceed. He is required by section 73 of the Land Titles Act to obtain a judgment before applying for a certificate of title to be issued in his name. However, it is suggested that before commencing an action for such judgment, he should also file a caveat on the certificate of title to protect his interest. This was not done by the plaintiff before the City registered its title to the Lots in question. According to Dobek v. Jennings, ${ }^{0}$ when a bona fide purchaser for value registers his transfer, in the absence of fraud, this registration extinguishes all unregistered rights that an adverse possessor may have had before. Therefore, the only way $\mathrm{Mr}$. Justice Farthing could have held in favour of Zbryski was to find that the City had become registered owner of the Lots in "actual" fraud of Zbryski.

Mr. Justice Farthing placed great emphasis on the fact that the plaintiff had been assessed, and had paid, taxes to the successive municipal authorities. He felt that payment of taxes for so many years created some kind of right in the plaintiff, and that the City's knowledge of this was an ingredient of fraud. He stated:

Had counsel for the City in his argument ... taken the position that obtaining title in the name of the defendant would, whether by law or by grace of the civic authorities, be, or be considered without prejudice to any rights the plaintiff may have had immediately before the registration, then of course, I could immediately dismiss any suggestion of fraud from mind.10

The fraud that Mr. Justice Farthing found was not fraud as contemplated by section 203 of the Land Titles Act, but rather, common law, or at least equitable, fraud. At page 66 he stated:

the action of the city officials concerned in lulling the plaintiff's solicitor into false security, relying upon their good faith is, I think, fraud at common law. But, if not, it appears to constitute 'equitable fraud', a phrase which has been held to cover "conduct which, having regard to some special relationship between the two parties concerned, is an unconscionable thing for the one to do towards the other....

Further,

as the defendant had knowledge of the claim of the plaintiff when it became registered owner by transmission, it is not in the position of an innocent purchaser for value without notice.

In summary, Mr. Justice Farthing considered the following points significant as indicating fraud: (1) the plaintiff's rights were prejudiced by the City when the latter obtained registration, (2) the City did not actively encourage the plaintiff to perfect his claim to title nor did it help him to do so, but merely told him to wait until a meeting of the Land Committee could be held (which amounted to fraud at common law), (3) that a special relationship existed between the parties and the City's unconscionable conduct toward the plaintiff amounted to equitable fraud, and (4) that the City, because it had knowledge of the plaintiff's' unregistered rights, was not a bona fide purchaser for value without notice.

It is submitted that if section 203 of the Alberta Land Titles Act is

9 Ibid.

10 Ante, n. 1 at 65. 
to be applied in its literal form, the reasons numbered (2) and (4) are insupportable. Section 203 reads:

Except in the case of fraud, no person contracting or dealing with or taking or proposing to take a transfer, mortgage, encumbrance or lease from the owner of any land in whose name a certificate of title has been granted shall be bound or concerned to inquire into or ascertain the circumstances in or the consideration for which the owner or any previous owner of the land is or was registered or to see to the application of the purchase money or any part thereof, nor is he affected by notice direct, implied or constructive, of any trust or unregistered interest in the land, any rule or law or equity to the contrary nothwithstanding, and the knowledge that any trust or unregistered interest is in existence shall not of itself be imputed as fraud.

The section protects a person taking a transfer from the registered owner of the land, except in the case of his own fraud, from the effect of any notice given him of another's equity or unregistered interest in the land. Knowledge of such equity or unregistered interest is not of itself considered to be fraud "any rule of law or equity to the contrary notwithstanding". This disposes of the fourth point in the summary of Mr. Justice Farthing's indications of fraud-that the City was not a "bona fide purchaser for value without notice". Its registered title could not be impugned despite its knowledge of the plaintiff's unregistered interest. It was only necessary that the City be a bona fide purchaser for value; notice was not a relevant consideration.

If a transferee's knowledge of a prior unregistered interest does not void his transfer, then certainly there is no duty upon him to help the holder of the prior interest, of which he knows, to become registered. This disposes of point number (2) above (common law fraud).

Section 203 has been argued in very few Alberta cases and has not been given its full literal effect by any Alberta court. However, the Saskatchewan counterpart of Alberta's section 203, section 216 (now section 237) of the Saskatchewan Land Titles Act, ${ }^{11}$ was given its full and literal effect in Hackworth v. Baker. ${ }^{12}$

In the Hackworth case, the plaintiff Hackworth obtained a transfer of a plot of farmland from her mother Mrs. Halcro. The plaintiff's consideration for the transfer was her undertaking to discharge a mortgage on the land and to pay the back taxes. The plaintiff did not register the transfer because she was not sure whether she could "handle" the mortgage and back taxes. The defendant Baker owned the land next to the plot in question, and expressed a desire to purchase the land from the plaintiff. His offer was refused and he dropped the matter until he learned that the property could be purchased for back taxes. When Baker investigated he learned that Mrs. Halcro was still the registered owner of the land. He then purchased the mortgage and made Mrs. Halcro a generous offer for the land, which the latter readily accepted because of Hackworth's failure to "handle" the mortgage and back taxes. Baker dealt entirely above board with Mrs. Halcro (although Hackworth did not learn about the transaction until later), and the transaction was completed in a lawyer's office. Baker later obtained registration of his title at the local Land Titles Office. The majority of the Saskatchewan Court of Appeal gave full effect to section 216 of the Saskatchewan Land

11 Ante, n. 4.

12 Ante, n. 3. 
Titles Act and held that Baker's mere knowledge of Hackworth's unregistered interest did not constitute fraud. Baker therefore was entitled to remain the registered owner of the land.

Mr. Justice Turgeon (later Chief Justice of the Saskatchewan Court of Appeal), who delivered the majority judgment in the Hackworth case, made an exhaustive review of the applicable case authorities and provisions of the Saskatchewan Land Titles Act. In reviewing the Act he quoted sections $60(1), 61,62(\mathrm{~d}), 63,65,216$ and 227 (These sections are the equivalent of sections 56, 63, 64(1) (d), 58, 203 and 207 of the Alberta Land Titles Act). Regarding these sections Mr. Justice Turgeon said:

Some of the cardinal principles of the Torrens registration system are embodied in these sections, and in one respect or another they are designed to do away with some of the rules of the old law of real property, and consequently with some of the difficulties and controversies to which the old rules gave rise. These sections establish:

(1) that estates and interests pass upon the registration and not upon the execution of the instrument; exception being made only in the case of certain leasehold interests;

(2) that priority dates from the time of registration and not from the time of execution; and

(3) that the registered owner, except in the case of his own fraud, holds his land free from all estates or interests not noted on the register, saving certain leasehold interests already mentioned, and subject to the reservations and incidents provided by the statute;

(4) that possession by another shall not derogate from the registered owner's right;

(5) that a person taking a transfer from the registered owner shall not, except in the case of his own fraud, be affected by any notice given him of another's equity or unregistered interest in the land; that, further on this point, knowledge of such equity or unregisterd interest shall not be considered a fraud; and it is expressly set out that this protection is to be given to the purchaser 'any rule of law or equity to the contrary notwithstanding'.

These provisions are all essential features of any land titles system; it is the right of registered owners and of those who deal with registered owners to revoke their protection and it is incumbent upon those who claim equities, or who retain in their own possession instruments, such as transfers, which might be registered, and which can pass no interest until they are registered, to bear them in mind. It is the intention of the statute that notice of rights and interests shall be given through the land titles office. This notice may be given by the registering of the instrument, the filing of a caveat, etc. according to the nature and convenience of the case. Otherwise the person claiming the right or interest is running the risk of seeing his claim extinguished even by the act of someone having notice of it. ${ }^{13}$ [Emphasis added]

This judicial review of the principles of the Torrens registration system aptly covers the law applicable in the Zbryski case.

Hackworth v. Baker has been applied and followed on its interpretation of the effect of section 216 of the Saskatchewan Land Titles Act in three subsequent Saskatchewan cases: Pfeifer v. Pfeifer, ${ }^{14}$ Canadian Superior Oil of California, Ltd. v. Cugnet, ${ }^{15}$ T. M. Ball Lumber Co. Ltd. v. Zirtz. ${ }^{16}$ Further, when the predecessor of Saskatchewan's section 216 came before the Supreme Court of Canada in Boulter-Waugh \& Co., Ltd. v. Union Bank of Canada, ${ }^{17}$ Mr. Justice Anglin (in the majority) stated:

I find in section 162 (216) the 'very explicit language' which I deem necessary to justify our regarding a statute as intended to render unenforceable such a

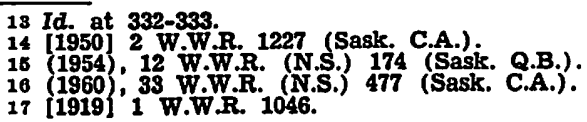


wholesome doctrine as that of the effect of notice in equity, to give effect to a provision that a person is to be unaffected by notice, his rights and remedies must be the same as they would have been had he not had notice. However wholesome we may consider the equitable doctrine as to the effect of noticehowever regrettable and even demoralizing in its tendency we may deem legislation rendering it inoperative-it is not in our power to disregard it. The legislative purpose being clear we have no right to decline to carry it out. Were we to do so consequences still more deplorable must ensue. The Court would occupy a wholly indefeasible position, one of usurpation of an authority, sovereign within its ambit, which it is its imperative duty to uphold. ${ }^{18}$

Therefore there is strong authority for regarding the Hackworth case as sound law. Clearly it should have been forcefully argued before Mr. Justice Farthing.

Returning to the four-point summary of Mr. Justice Farthing's reasons for finding fraud, reason number (1) (plaintiff's rights being prejudiced by the City obtaining registration of its title to the lots) was argued before the Court in the Hackworth case and appeared as obiter in the judgment of the Alberta Supreme Court in Sydie v. Saskatchewan and Battle River Land Co. Ltd. ${ }^{19}$ The Court in the latter case made a finding of fraud and, after reference to an exerpt from Hogg's Austrialian Torrens System, ${ }^{20}$ the following statement was made:

A very logical distinction is there suggested between mere knowledge of the existence of an unregistered interest which may not necessarily be hurt by the transaction attached and knowledge that the effect of that transaction will be to injure or destroy that interest. The knowledge that such will be the effect is obviously something more than mere knowledge of the existence of that interest.21

Mr. Justice Turgeon in the Hackworth case rejected this distinction because it failed to distinguish between valid and invalid transactions, which was the essential point. He said:

If nobody is "hurt", if nobody's interest is injured or lost, there is no cause for litigation. If nobody is to be hurt or injured, there is no sense in saying that the registered instrument taken with notice or knowledge, is to take precedence over the unregistered one of prior execution, "any rule of law or equity to the contrary notwithstanding'. These words can only mean that the unregistered claimant may be deprived of a right to the property which would be his by law or by some rule of equity, had not the Legislature stepped in to put the other party ahead of him. ${ }^{22}$

It is submitted that $\mathrm{Mr}$. Justice Turgeon's reasons for disposing of the "hurt" argument are founded upon good sense as well as sound law. Thus the "hurt" reason for finding fraud in the Zbrystei case is disposed of.

This leaves only the third of Mr. Justice Farthing's reasons for finding fraud-that of a special relationship between the parties. With respect, it is difficult to ascertain on what grounds Mr. Justice Farthing found this special relationship. The only possible explanation might run as follows: the plaintiff having approached the City with his claim, relied entirely upon the "good faith" of the City to grant his request. Mr. Justice Farthing seemed to feel that the City was placed in a fiduciary, or even a paternal relationship, with a duty to inform the plaintiff of his full rights and to aid him in obtaining title. He stated:

The evidence makes it abundantly clear that the land department misled the plaintiff's solicitors throughout. The latter presumed, naturally, that they were

$18 \mathrm{Id}$. at 1054

19 (1913), 5 W.W.R. 194.

20 Hogg's Australian Torrens System 835 (1905).

21 Ante, n. 19, at 198.

22 Ante, n. 3, at 341. 
negotiating in good faith. The officials of the city persisted week after week, sometimes by letter, more often by telephone conversation, in assuring plaintiff's solicitor that the Land Committee would consider the matter. Far from urging them to hurry to establish their client's claim, if they could, or lose it, they were lulled into an assurance of false security by being told repeatedly that the Land Committee would consider the matter. ${ }^{23}$

This entirely overlooks two important points: (1) that the City in no way deceived the plaintiff as to his legal rights nor prevented his solicitor from filing a caveat, and (2) that the Land Committee was under no obligation to grant the plaintiff's request.

The writer's submission is, with respect, that Mr. Justice Farthing was not justified in finding that a special relationship existed between Zbryski and the City merely because Zbryski presented an imperfect claim before the City and anticipated that because he came there in "good faith" the City would overlook all imperfections. Even more important, it was assumed that the City would forego its own legal rights. All the City did was rely and act upon its statutory rights-viz., to rely on the certificate of title as conclusive of all that it contains, and to deal as a bona fide purchaser for value with the registered owner. As stated by Mr. Justice Turgeon in the Hackworth case: "to take advantage of a statutory right is not to cheat, although of course, the other party must necessarily suffer by the taking of such advantage." 24

No representation or promise to grant the plaintiff a transfer was made by the City. The only possible "representation" was the one made by the Land Department that it would consider the plaintiff's claim, and that, it is suggested, was not a material representation upon which fraud could be found under section 203.

Although Mr. Justice Farthing accepted the plaintiff's argument that they became owners of the land by adverse possession as attested by the collection of taxes from them ... [and] the defendant is estopped from denying their title, ${ }^{25}$ he felt that Lord Denning's theory of promissory estoppel expressed in Central London Property Trust, Ltd. v. High Trees House, $L t d .^{20}$ applied, though he gave no reasons for so holding. However, even equitable or promissory estoppel requires that a "promise" be made and acted upon, which was not the case here. Therefore no special relationship existed by virtue of a contract, representation, promise, or any other form of special relationship recognized by law.

Section 203 does not abrogate the application of fraud under the Land Titles Act. Fraud still has some purview, but knowledge of an unregistered interest in itself does not constitute fraud. Something more than mere knowledge of an unregistered interest or equity is required. Mr. Justice Turgeon in the Hackworth case gave some indication of what that "something more" might be:

Surely these bare facts cannot constitute fraud within the statute. Baker stood in no confidential relationship to the plaintiff, he did not get his transfer for nothing, nor with any limitations attached to it by the transferor, he did not take advantage of a mistake made by the plaintiff in dealing with him, he did not resort to any deliberate and dishonest trick to prevent the plaintiff from registering her transfer, in short there is no particular act or circumstance in his

28 Ante, n. 1, at 65.

24 Ante, n. 3 , at 348 .

25 Ante. n. $\frac{1}{1}$ at 67. 
case which, in line with precedent, can be said to spell fraud so as to defeat a statute which abolishes the legal and equitable effect of notice.27

The two earlier Alberta cases in which fraud was found are consistent with Mr. Justice Turgeon's suggestions. In Sydie v. Saskatchewan and Battle River Land Co., ${ }^{28}$ Sydie bought certain lots in Edmonton from the defendant company, of which one Brown was secretary-treasurer. Brown negotiated the sale to Sydie. One of the lots was a corner lot, described as Lot 15 in block 5. An agreement for sale was executed, Brown signing for the defendant company, and Sydie made a part payment. Later, fire destroyed the records of the defendant company, and Sydie was contacted and asked for a description of the lots he had bought. By mistake Sydie, in answering, said he had bought lot 15 in block 15, instead of block 5. Brown saw this and knew it was a mistake, as did the defendant company. Thereupon they took advantage of Sydie's mistake to put through and register a transfer of this corner lot from the company to Brown. The Court found fraud and cancelled Brown's certificate of title in favour of Sydie. In this case not only did Brown take advantage of a mistake made by Sydie in the dealing, but he also supplied no consideration for his transfer.

The other Alberta case in which fraud was found is Pick v. Pick and Pisz (or Pich) ${ }^{29}$ decided in the Alberta Supreme Court, Appellate Division. There the plaintiff and defendant, half-brothers, had each received a transfer of one-half of their father's quarter section. Neither party had registered his transfer. The defendant and the father later colluded to deprive the plaintiff of the land transferred to him. The father purported to transfer the whole of the quarter section to the defendant. The defendant later registered this transfer. The Court held that the defendant had procured the transfer of the whole quarter section to himself in actual fraud of the plaintiff. Section 189 (203) of the Alberta Land Titles $\mathrm{Act}^{30}$ was relied upon by the Court as precluding the defendant from retaining registration of his title. On the question of fraud Mr. Justice Frank Ford (for the Court) stated:

He [defendant] could not and did not honestly believe that his father had the right to transfer the west half of the quarter section to him ... When he conceived the idea that he might take advantage of some difficulties which had arisen between Wasyl [plaintiff] and his father he took his father to another solicitor from whom he concealed all knowledge of what had been done by $\mathrm{Mr}$. Basqrak [the solicitor who prepared the original two transfers to the plaintiff and defendant $].{ }^{31}$

It is submitted that fraud was found in the Pick case because of the existence of a special relationship between the parties. This arose out of the close blood relationship coupled with the fact that the three had been parties to the original transaction whereby the plaintiff and the defendant had obtained their original transfers and had agreed to jointly provide for the care and maintenance of their father. This case then is also consistent with one of Mr. Justice Turgeon's suggested cases of fraud-viz., that of a special or confidential relationship.

\footnotetext{
27 Ante, n. 3, at 346-347.

28 Ante, n. 19.

29 [1947] 1 W.W.R. 428.

30 R.S.A. 1942, c. 205.

31 Ante, n. 29, at 437 .
} 
In conclusion, it is apparent that the two previous Alberta cases are consistent with the law as laid down in Hackworth v. Baker. ${ }^{22}$ Only Zbryski v. City of Calgary presents a digression. It is submitted that the "something more" than mere knowledge required to find fraud under section 203 did not exist in the Zbryski case. This being so, $\mathrm{Mr}$. Justice Farthing was not, with respect, justified in finding fraud. However much $\mathrm{Mr}$. Justice Farthing may have felt that the law would work an injustice on Zbryski, the law must be recognized and given effect to.

Perhaps it would not be inappropriate to conclude by noting that Zbryski's solicitor could have avoided a great deal of ill-will and litigation had he advised Zbryski to file a caveat to protect his claim before the City of Calgary became registered.

HENRY J. BUDNITSKY*

82 Ante, n. 3. (Alta.). of the 1966 graduating class. 